\title{
Effect of electroconvulsive therapy on serum myelin basic protein immunoreactivity
}

\begin{abstract}
A sensitive radioimmunoassay that can detect brain damage in cases of head injury and stroke was applied to blood samples from 13 patients before and after they received multiple treatments with electroconvulsive therapy for psychiatric disorder. None of the patients showed a significant increase in serum myelin basic protein immunoreactivity. As increased serum myelin basic protein immunoreactivity may reflect myelin damage it is apparent that in these patients electroconvulsive therapy did not cause measureable breakdown of myelin.
\end{abstract}

\section{Introduction}

Although electroconvulsive therapy is an established technique, its therapeutic efficacy has been questioned and studied in clinical trials that have produced conflicting results. ${ }^{1}$ The procedure carries serious risks, the principal ones being myocardial infarction or cardiac arrhythmias that may prove fatal. Changes in brain function, particularly in memory, may occur and are sometimes permanent. Experimental work indicates that electroconvulsive therapy may cause temporary changes in the normal blood-brain barrier, with an increase in permeability. ${ }^{2}$

Myelin basic protein is one of the best characterised of the antigens specific to the central nervous system and constitutes $30 \%$ of the myelin sheath. ${ }^{3}$ Myelin basic protein immunoreactivity in serum and cerebrospinal fluid has been correlated with the degree of damage to the central nervous system produced in

Gough-Cooper Department of Neurological Surgery, National Hospitals for Nervous Diseases, Queen Square, London WC1E 3BG

N R HOYLE, BSC, research assistant

D G T THOMAS, MRCP, FRCSED, senior lecturer and consultant neurosurgeon

Department of Psychological Medicine, National Hospitals for Nervous Diseases

R T C PRATT, FRCP, FRCPSYCH, consultant psychiatrist (Dr Pratt died in March 1983)

Correspondence and reprint requests to: $\mathrm{Mr} \mathrm{N}$ R Hoyle. varying neurological conditions including trauma, stroke, demyelinating disease, and neurosurgical operations. ${ }^{4}$ We carried out this study to investigate whether serum immunoreactivity of myelin basic protein would rise during courses of electroconvulsive therapy.

\section{Patients, methods, and results}

We studied 13 patients (five men, eight women; age range 28-76 (mean 58)) who were being treated with electroconvulsive therapy. Eleven of the patients had endogenous depression. The number of treatments the patients received varied from three to 41 (mean 16), and the maximum duration of the course of treatment was seven months. Patients usually received two treatments a week, although three patients received three a week. Treatment was applied unilaterally, the range of energy given being 10-50 J (mean $30 \mathrm{~J}$ ).

Fourteen volunteers (nine men, five women; age range 21-35 (mean 26)) served as controls and were each studied two or three times a month over a five month period.

Venous blood samples were taken from the patients immediately before treatment and again 15 minutes after treatment. The samples were stored at $-75^{\circ} \mathrm{C}$ and assayed within 14 weeks of collection. A total of 417 samples was obtained over seven months. Using a previously described method, we measured serum myelin basic protein immunoreactivity by a competitive inhibition double antibody radioimmunoassay.

In the controls serum myelin basic protein immunoreactivity ranged from $<3$ to $17 \mu \mathrm{g} / 1$ (mean (SD) $7 \cdot 2(1 \cdot 3) \mu \mathrm{g} / \mathrm{l}$ ). In the 13 patients serum myelin basic protein immunoreactivity ranged from $<3$ to $41 \mu \mathrm{g} / 1$; the mean before the course of electroconvulsive therapy was $9.21(0.42) \mu \mathrm{g} / 1$ and after the course $9.77(0.45) \mu \mathrm{g} / \mathrm{l}$. The table shows the results in each patient.

Statistical analysis-A paired Student's $t$ test was performed on the mean immunoreactivity before and after treatment, yielding $p=$ $0 \cdot 192$. Pearson's correlation coefficient analysis was used to determine whether there was any uniform change in the trend of myelin basic protein immunoreactivity during the course of a patient's treatment; this yielded non-significant results in all 13 patients.

\section{Discussion}

The control group showed consistently stable serum myelin basic protein immunoreactivity throughout the study; serum myelin basic protein immunoreactivity in the patients was not significantly different from that in the controls.

Details of patients given electroconvulsive therapy (ECT)

\begin{tabular}{|c|c|c|c|c|c|c|c|c|c|c|}
\hline \multirow{2}{*}{$\begin{array}{l}\text { Case } \\
\text { No }\end{array}$} & \multirow{2}{*}{ Sex } & \multirow{2}{*}{$\begin{array}{c}\text { Age } \\
\text { (years) }\end{array}$} & \multirow{2}{*}{ Psychiatric diagnosis } & \multirow{2}{*}{ Associated features } & \multirow{2}{*}{$\begin{array}{c}\text { Energy } \\
\text { applied } \\
\text { on ECT }(J)\end{array}$} & \multirow{2}{*}{$\begin{array}{l}\text { Previous } \\
\text { ECT }\end{array}$} & \multirow{2}{*}{ Outcome } & \multirow{2}{*}{$\begin{array}{l}\text { No of } \\
\text { treatments }\end{array}$} & \multicolumn{2}{|c|}{$\begin{array}{l}\text { Log mean (SEM) myelin basic protein } \\
(\mu \mathrm{g} / 1)\end{array}$} \\
\hline & & & & & & & & & Before treatment & After treatment \\
\hline 1 & $\mathbf{M}$ & 58 & Depression & Guillain-Barré 1 year & 30 & Yes & Improyed & 18 & $0.696(0.087)$ & $0.641(0.086)$ \\
\hline $\begin{array}{r}2 \\
3 \\
4 \\
5 \\
6 \\
7 \\
8 \\
9 \\
10 \\
11 \\
12 \\
13\end{array}$ & $\begin{array}{l}\mathbf{F} \\
\mathbf{M} \\
\mathbf{F} \\
\mathbf{F} \\
\mathbf{M} \\
\mathbf{F} \\
\mathbf{F} \\
\mathbf{F} \\
\mathbf{M} \\
\mathbf{F} \\
\mathbf{F} \\
\mathbf{F}\end{array}$ & $\begin{array}{l}65 \\
58 \\
68 \\
69 \\
42 \\
76 \\
69 \\
55 \\
60 \\
28 \\
67 \\
54\end{array}$ & $\begin{array}{l}\text { Depression } \\
\text { Depression } \\
\text { Depression } \\
\text { Personality disorder } \\
\text { Personality disorder } \\
\text { Depression } \\
\text { Depression } \\
\text { Depression } \\
\text { Depression } \\
\text { Depression } \\
\text { Depression } \\
\text { Depression }\end{array}$ & $\begin{array}{l}\text { Parkinson's disease } \\
\text { Epilepsy } \\
\text { Multiple sclerosis } \\
\text { Parkinson's disease }\end{array}$ & $\begin{array}{l}30 \\
15 \\
20 \\
40 \\
20 \\
30 \\
30 \\
30 \\
20 \\
40 \\
25 \\
15 \\
20\end{array}$ & $\begin{array}{l}\text { No } \\
\text { Yes } \\
\text { No } \\
\text { Yes } \\
\text { No } \\
\text { Yes } \\
\text { No } \\
\text { No } \\
\text { No } \\
\text { No } \\
\text { Yes } \\
\text { Yes }\end{array}$ & $\begin{array}{l}\text { Recovered } \\
\text { Improved } \\
\text { Improved } \\
\text { Unchanged } \\
\text { Unchanged } \\
\text { Improved } \\
\text { Slight improvement } \\
\text { Improved } \\
\text { Improved } \\
\text { Slight improvement } \\
\text { Improved } \\
\text { Improved }\end{array}$ & $\begin{array}{r}4 \\
27 \\
17 \\
3 \\
18 \\
25 \\
5 \\
12 \\
23 \\
11 \\
39 \\
3\end{array}$ & $\begin{array}{l}1.075(0.067) \\
0.668(0.052) \\
0.958(0.062) \\
0.873(0.166) \\
1.067(0.053) \\
0.912(0.033) \\
0.756(0.138) \\
0.624(0.074) \\
1.054(0.070) \\
0.758(0.105) \\
0.933(0.041) \\
0.560(0.139)\end{array}$ & $\begin{array}{l}1.101(0.102) \\
0.818(0.049) \\
0.910(0.063) \\
1.142(0.096) \\
1.051(0.070) \\
0.926(0.045) \\
0.867(0.190) \\
0.705(0.073) \\
1.026(0.069) \\
0.882(0.092) \\
0.949(0.040) \\
0.543(0.195)\end{array}$ \\
\hline
\end{tabular}


There are obvious practical difficulties in monitoring transitory changes to the blood-brain barrier that may occur during electroconvulsive therapy, and little study has been made of such changes. Bolwig et al found an enhanced passage of horse radish peroxidase across the rat blood-brain barrier lasting for from 30 to 60 seconds during an epileptic seizure induced by electric shock. ${ }^{2}$ They proposed that the increased permeability was due not to epileptic neuronal activity but rather to acute hypertension. In earlier work they had reported a considerable temporary increase in cerebral blood flow and an increase in the permeability of the blood-brain barrier to small molecules in patients receiving electroconvulsive therapy. ${ }^{6}$

Though it is unlikely that a single blood sample taken 15 minutes after treatment would show altered serum myelin basic protein immunoreactivity, any change in immunoreactivity during a course of treatments over several months would presumably be detected. In this study electroconvulsive therapy, either as a single episode or as a course of treatments, did not affect serum myelin basic protein immunoreactivity. This suggests that, at least in so far as serum myelin basic protein immunoreactivity can be assumed to be a marker of cerebral damage and vascular permeability, no changes occurred; if they did they were so transient or small that they were undetectable by this method.

\section{References}

${ }^{1}$ Kendall RE. The present status of electroconvulsive therapy. $\mathrm{Br} \mathrm{F}$ Psychiatry 1981;139:265-83.

2 Bolwig TG, Hertz MM, Westergaard E. Acute hypertension causing bloodbrain barrier breakdown during epileptic seizures. Acta neurol Scand $1977 ; 56: 335-42$.

${ }^{3}$ Eng LF. Brain related antigens. In: Thomas DGT, Graham DI, eds. Brain tumours: scientific basis, clinical investigation and current therapy. London: Butterworths, 1979:109-20

${ }^{4}$ Biber A, Englert D, Dommasch D, Hempel K. Myelin basic protein in cerebrospinal fluid of patients with multiple sclerosis and other neurological diseases. $\mathcal{F}$ Neurol 1981 ;225:231-6.

${ }^{5}$ Palfreyman JW, Thomas DGT, Ratcliffe JG. Radioimmunoassay of human myelin basic protein in tissue extract, cerebrospinal fluid and serum and its clinical application to patients with head injury. Clin Chim Acta 1978;82:259-70.

${ }^{6}$ Bolwig TG, Hertz MM, Paulson OB, Spotoft H, Rafaelson OJ. The permeability of the blood-brain barrier during electrically induced seizures in man. Eur $\mathcal{F}$ Clin Invest 1977;7:87-93.

(Accepted 13 fanuary 1984)

\title{
Carcinoid tumour secreting dopa
}

\author{
B K SHARMA, B J SMITS, R ROBINSON, SYLVIA BURNS, E N TROUNSON
}

\begin{abstract}
A middle aged woman referred for an abdominal mass was found to have large amounts of dopa (3-4-dihydroxyphenylalanine) metabolites in her urine. At operation a tumour affecting almost the entire left lobe of the liver was removed. Histologically the tumour was a metastatic carcinoid. After operation the excretion of dopa metabolites fell substantially, confirming that the tumour was the source. Apparently owing to an enzyme defect the tumour had been unable to decarboxylate dopa.

These findings are further evidence of a neural origin for the endocrine system of the gut.
\end{abstract}

\section{Introduction}

Both carcinoid tumours and phaeochromocytomas cause distinctive clinical features by the production of highly reactive amines from aromatic amino acids. Their origin has been ascribed to cells of the APUD (amine precursor uptake and decarboxylation) series. ${ }^{1}$

Carcinoid tumours typically convert tryptophan to 5hydroxytryptophan and 5-hydroxytryptamine. Phaeochromo-

George Eliot Hospital, Nuneaton, Warwickshire CV10 7BL

B K SHARMA, MB, MRCP, medical registrar

B J SMITS, MB, FRCP, consultant physician

E N TROUNSON, FRCPATH, consultant pathologist

Warwick General Hospital, Warwick CV34 5BW

R ROBINSON, PHD, FRSC, chief biochemist

SYLVIA BURNS, BSC, biochemist

Correspondence to: Dr B J Smits, Department of Gastroenterology, Walsgrave Hospital, Coventry CV2 2DX. cytomas and neuroblastomas decarboxylate dopa (3-4-dihydroxyphenylalanine) to form dopamine, noradrenaline, and related catecholamines; malignant variants may lack decarboxylase and secrete the amine precursor, dopa. We describe a patient suffering from a histologically proved carcinoid tumour who was found to be excreting large quantities of dopa metabolites.

\section{Case history}

A 56 year old woman had complained of epigastric pain for eight to 10 years with intermittent attacks of fever and jaundice. An abdominal mass had been present for a similar period, which was thought to be a pancreatic cyst. She was referred to the gastroenterology clinic, and a hard, irregular mass descending $8 \mathrm{~cm}$ from the costal margin was noted. She appeared otherwise well and was neither anaemic nor jaundiced. A grade $3 / 6$ systolic murmur was heard maximally at the lower left sternal edge. Blood pressure was stable at $110 / 70 \mathrm{~mm} \mathrm{Hg}$. Isotope and computed tomographic scans indicated hepatic metastases. At laparotomy the left lobe of the liver was almost entirely replaced by tumour; it was excised. No primary growth was identified.

\section{BIOCHEMICAL FINDINGS}

In view of the duration and nature of the enlarged liver a diagnosis of metastatic carcinoid seemed likely; however, urinary excretion of 5-hydroxyindole acetate was normal. By chance, a urine specimen was examined chromatographically for phenolic acids. Large amounts of dopa metabolites were found, particularly 4-hydroxy-3-methoxyphenyllactic acid and homovanillic acid. After operation the urinary output of both these metabolites fell substantially; 4-hydroxy-3methoxyphenyllactic acid was no longer detectable and excretion of homovanillic acid was only marginally raised.

The tumour tissue was examined by high performance chromatography. There were no detectable amounts of 5-hydroxytryptamine, 5-hydroxytryptophan, dopamine, or noradrenaline, but a substance with the chromatographic mobility of dopa was present. Neither dopa decarboxylase nor dopamine $\beta$-hydroxylase was detected. 